\title{
超電導電力貯蔵装置（SMES）の冷却システム
}

\author{
平野 直樹 ${ }^{*}$, , 渡部 智則 ${ }^{*}$, 長屋 重夫*
}

\section{Cooling Technologies for SMES}

\author{
Naoki HIRANO ${ }^{*}$, , Tomonori WATANABE ${ }^{*}$ and Shigeo NAGAYA ${ }^{*}$
}

\begin{abstract}
Synopsis: As energy storage equipment for electric power systems, superconducting magnetic energy storage (SMES) systems have good characteristics such as high efficiency, quick response and no deterioration under repeated operations. Since 1991, a national project by the Agency for National Resources and Energy Japan has been carried out to develop an SMES system for power control in a power system. Moreover, SMES has been developed as a bridge for instantaneous voltage dips since 2003. In this issue, cooling systems and cryocoolers for SMES are introduced.
\end{abstract}

Keywords: SMES, cryocooler, liquid helium, pulse tube, inverter control

(Some figures in this article may appear in colour only in the electronic version)

\section{1. はじめに}

超電導電力貯蔵（SMES：Superconducting Magnetic Energy Storage）と呼ばれる電力貯蔵法は、超電導現象である電気 抵抗がゼロとなる特長を利用し、超電導線でコイルを作り、 そこに電気を流しても超電導コイルのみで閉回路を構成す れば、その回路内を電流が減衰することなく流れ続け、電 力をエネルギー変換なく貯蔵する技術である。他の電力貯 蔵手法が例えば一旦電気エネルギーを化学エネルギーや回 転エネルギーなどエネルギー変換を伴うのに比べ、電気を 磁気エネルギーの形で貯蔵することから、エネルギー変換 によるロスがなく、高い貯蔵効率を有することが特長とし て挙げられる。加えて、1 秒程度の短時間で貯蔵全エネル ギーを放出したり、数万、数十万回もの繰返し充放電に対 して貯蔵部が劣化しない特長も有する。SMES は、すでに 瞬時電圧低下補償（以下、瞬低補償）用途への実用化が実 現しており、三重県亀山市の最新鋭液晶テレビ工場をはじ め国内 3 か所で実稼働している。また、瞬低補償用 SMES に比べ、もう一段高度な技術を必要とする電力系統制御用 SMES の開発が 1991 年から 2012 年まで国家プロジェクト として進められた。中でも、2007 年には、実系統に SMES を連系し、負荷変動補償機能や系統安定化機能の実証が行 われている。ここでは、瞬低補償用 SMES や国家プロジェ

\footnotetext{
Received February 28, 2014

* 中部電力 (株) 電力技術研究所 流通グループ 超電導チーム

干 459-8522 愛知県名古屋市緑区大高町字北関山 20-1

Chubu Electric Power Co., Inc., Electric Power R\&D Center, 20-1

Kitasekiyama, Ohdaka-cho, Midori-ku, Nagoya, Aichi 459-8522, Japan

† E-mail: Hirano.Naoki@chuden.co.jp

DOI : $10.2221 /$ jcsj.49.295
}

クトとして進められた電力系統制御用 SMES、ならびに SMES 用酸化物コイルの開発状況を紹介した上で、SMES の冷却設備にスポットを当てて解説する。開発が進められ ている酸化物コイル伝導冷却技術や小型冷凍機のインバー タ化による省エネ技術についても紹介する。

\section{SMES の原理と特徵}

SMES は、超電導の電気抵抗ゼロの特長を利用し、電気 エネルギーを磁気エネルギーとして貯蔵する装置である。 超電導線で作られたコイルに電流を流した場合、電気抵抗 がないために、コイルを流れる電流の減衰時定数は無限大 となる。この時、コイルの両端を閉じると電流は減衰する ことなくコイルの中を流れ続け、電流が作る磁場が発生し 続けることになる。これにより、磁気エネルギーとして電 力が保存された状態となり、これが超電導エネルギー貯蔵 の原理である。

SMES コイルに貯蔵されるエネルギーは、コイルのイン ダクタンス（L) と通電電流（I）で決まり、(1/2) L・ I ${ }^{2} の$ エネルギーを貯蔵することができる。 SMES では、電力が コイルに電流を流し続けることで一定の磁界が発生する形 として蓄えられている状態となるので、他の貯蔵手法に比 ベ電力の変換効率が高く、入出力の瞬時応答性、例えば 1 秒で貯蔵しているエネルギーを放出したり、有効・無効電 力の独立制御、更には数万、数十万回もの繰返し充放電に 対して貯蔵部が劣化しない長寿命などの特徴を持つ。ま た、目的に応じた必要貯蔵エネルギー量で、その貯蔵部を 構成できるという特徵を持つ。具体的な用途で言えば、瞬 低補償であれば 1 秒も出力できればよく、SMES では 1 秒 間に大出力できるだけのコンパクトな貯蔵部が実現できる 
が、二次電池のような貯蔵技術では大出力化のために電池 の直並列数を増加させなければならず、結果として数時間 以上出力可能な大容量貯蔵部を背負うことになる。

Fig. 1 に SMES のエネルギー充放電原理を示す。電力系 統と超電導コイルの間には、交流電流と直流電流を変換す る装置や遮断器を持ち、超電導コイル充電時には超電導コ イルで閉回路を構成し、コイルに直流電流を流し続けるこ とでエネルギーを貯蔵する。放電時には超電導コイルと変 換器の回路を閉じ、コイルの直流電流を外部にエネルギー として取り出す。

\section{SMES 開発動向}

超電導状態では大電流を効率良く取り扱えるため、電流 密度を高めることができ、電力機器においては大幅なコン パクト化が可能となる。このため、多くの用途において、 容量に対するスケールメリットが大きく発揮されるが、 SMES においても、高い電力の貯蔵効率とその優れた耐久 性の特徵も加わって、1970 年代には、昼夜の負荷平準化 などの大規模電力貯蔵技術として、貯蔵容量が数百 MWh か ら数 GWh 級の SMES が検討された。しかしながら、この ような揚水発電の代替えも視野に入れた大型 SMES は、 コイルが発生する電磁力支持に、地下の岩盤利用も想定す るような大規模なシステムであり課題も多いため、まず市 場ニーズもあり、技術的に実現可能な SMES とするため に、秒単位の応用となる系統安定化用や瞬時電圧低下（以 下、瞬低という）補償用の SMES の開発が進められた。

欧米では、米国企業の 1〜3 MJ 級の金属系 SMES が瞬 低補償用等に一部導入された実績がある。最近、米国では 2010 年度から、イットリウム系超電導線材を用いた 3.4 MJ @ 4.2 K \& 30 T の超高磁場 SMES の開発が 3 年計画で 開始されており、ABB 社が主体で SuperPower 社、ブルッ クヘブン（Brookhaven）国立研究所が開発を推進してい る 1)。フランスにおいても電磁推進用パルス電源として SMES の開発が行われており、Bi 系超電導線材を使用し て $0.8 \mathrm{MJ}$ 級のコイル製作評価が実施されている ${ }^{2)}$ 。

アジアでは、韓国、中国やインドにおいて MJ 級の金属 系 SMES が既に開発されている状況にある。

日本における本格的な SMES 開発は、資源エネルギー 庁の国家プロジェクトとして電力系統制御用 SMES の開 発が、1991 年から産学官を挙げて始められた。また、同 プロジェクトで超電導コイルのコスト低減に目処が立った ことから、瞬時の放電動作のみでその責務を果たすことが できる瞬低補償システムが実用化されている。以下、瞬低 補償用と電力系統制御用の SMES 開発状況を簡単に紹介 する。

\section{1 瞬低補償用 SMES の開発}

SMES は、瞬間に大電力の出し入れが可能で貯蔵効率も 高いことから、瞬低補償用に最適な電力機器である。工場

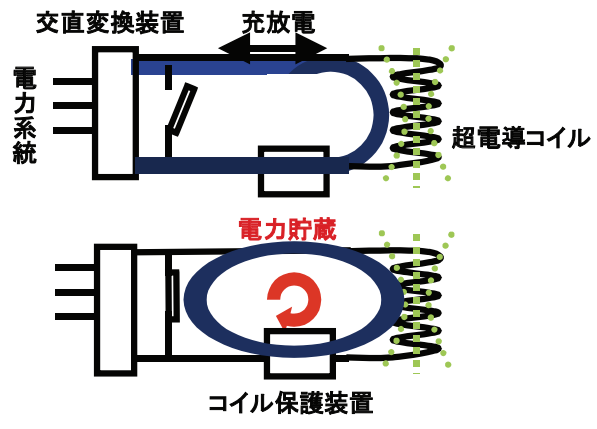

Fig. 1 Principle underlying the charge and discharge of SMES.

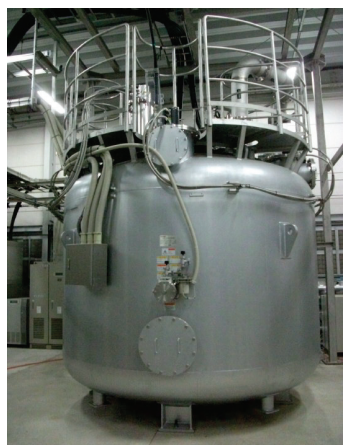

Fig. 2 Overview of 10 MVA-20 MJ SMES for bridging instantaneous voltage dips.

Table 1 Specifications of 10 MVA-20 MJ SMES for bridging instantaneous voltage dips

\begin{tabular}{l|l}
\hline Coil configuration & Four-pole coil arrangement \\
\hline Rated current & $1,400 \mathrm{~A}$ \\
\hline Rated voltage & $6,000 \mathrm{VDC}$ \\
\hline Inductance & $21.1 \mathrm{H}$ \\
\hline Stored energy & $20.7 \mathrm{MJ}$ \\
\hline Maximum field & $4.4 \mathrm{~T}$ \\
\hline Cooling method & LHe pool boiling \\
\hline Rated output & $10 \mathrm{MVA} 1 \mathrm{~s}$ \\
\hline Change over time & $1 / 4$ cycle $+\alpha$ \\
\hline
\end{tabular}

を一括で瞬低補償できる大出力が可能なシステムを実現す るため、高圧機器と浸漬冷却超電導コイルとして高電圧化 を図った固体絶縁コイルを組み合わせ、待機時の損失を低 減できる常時商用給電方式を採用するとともに、瞬低発生 時の電力系統からの切替時間を $1 / 2$ サイクルとした世界最 大規模の出力 5〜10 MVA、補償時間 1 秒の瞬低補償システ ムが開発された。すでに、インバータやモータ等の多様な 負荷が混在した国内の最新鋭液晶 T V 工場内にて、2003 年 7 月より 5 MVA 機のフィールド試験 ${ }^{3)} 、 2005$ 年 10 月から は 10 MVA 機のフィールド試験が実施された。これまでに 40 回以上の瞬低補償動作が確認されており、現在も出力 4〜 10 MVA、貯蔵エネルギー10～20 MJ 級の金属系超電導 体のコイルを用いた SMES が国内 3 か所で実運用されてい る。実運用中の 10 MVA 機エネルギー貯蔵部外観を Fig. 2 に、緒元を Table 1 に示す。 


\section{2 電力系統制御用 SMES の開発}

国内における本格的な電力系統制御用 SMES 開発は、 1991 年から資源エネルギー庁の国家プロジェクトとして 産学官を挙げて進められた。第 1 期の要素技術開発におい て、100 kWh 級の多目的 SMES が金属系超電導体を用い て実現可能であることが示されたが、コスト面の課題も明 らかになり、引き続き実施された第 2 期の開発（1999〜 2003 年度）では、当時システムコストの大半を占めてい た超電導コイル部分に対して検討を行い、目的に応じた機 能に最適化させることで、コス卜低減可能な技術が開発さ れた。その結果、SMES の本体となる超電導コイルは、従 来の $1 / 6$ 程度で作製可能となる見通しが得られ、要素モデ ルコイルによる性能実証試験が、中部電力寛政変電所内の 超電導試験センターにて実施された。定格通電電流 $10 \mathrm{kA}$ の大電流コイルで、18 秒周期の変動負荷補償として過去 に例のない連続 1 万回の充放電試験を行い、電力系統制御 装置としての優れた性能が証明されている ${ }^{4)}$

さらに 2004 年からの第 3 期国家プロジェクトでは、 SMES の電力系統制御システムとしての機能検証を目指し た開発が行われた。 1 万 $\mathrm{kW}$ 級（貯蔵エネルギー20 MJ 級） SMES を製作し、負荷の変動による電力系統への影響 を低減させる機能や発電機が停止するなどの外乱により電 力系統が不安定となることを防ぐ機能を、工場での試験に よる要素機器毎の性能検証試験のみでなく、要素機器をシ ステムとして組合せ、その効果を実地で確認するために、 実系統に連系して試験が行われた。SMES 実系統連系試験 システムの鳥瞰図を Fig. 3 亿示寸。SMES は、Fig. 4 亿示寸 ように、栃木県日光市にある古河日光発電株式会社細尾発 電所 $11 \mathrm{kV}$ 母線に接続され、分岐線の電流、電圧を計測 し、隣接工場の電気炉等の運転に伴う有効・無効電力の変 動を補償するように SMES は運転し、負荷変動の補償効果 が確認された。繰り返し補償動作は、当初目標の 2 万回以 上に対して、5 万回以上の動作実績を残し、耐久性・安定 性が確認された ${ }^{5)}$ 。なお、第 3 期のプロジェクトでは、実 系統連系試験の他に、コイル冷却等に不可欠な極低温冷凍 機の信頼性向上についても開発が行われており、その成果 も次節で紹介寸る。

\section{3 酸化物系 SMES コイルの開発}

これまで紹介してきた SMES は、金属系超電導体を用い たコイルによる SMES であり、超電導状態を維持するため に液体へリウム温度域（マイナス $269^{\circ} \mathrm{C}$ ）に冷却寸る特殊 なシステムが必要となる。このため、コスト面の从ならず 運用・保守の面からも制約があり、幅広く普及させるに は、更なる技術革新が求められてきた。高温超電導体、中 でもイットリウム系超電導体は磁場中でも通電特性に優 れ、SMES の高磁界化が可能で、また線材自体に機械強度 の高い基材が使用可能であるため、高磁界化コイルでの課 題となる高耐電磁力化が容易となる。他の電力貯蔵技術に

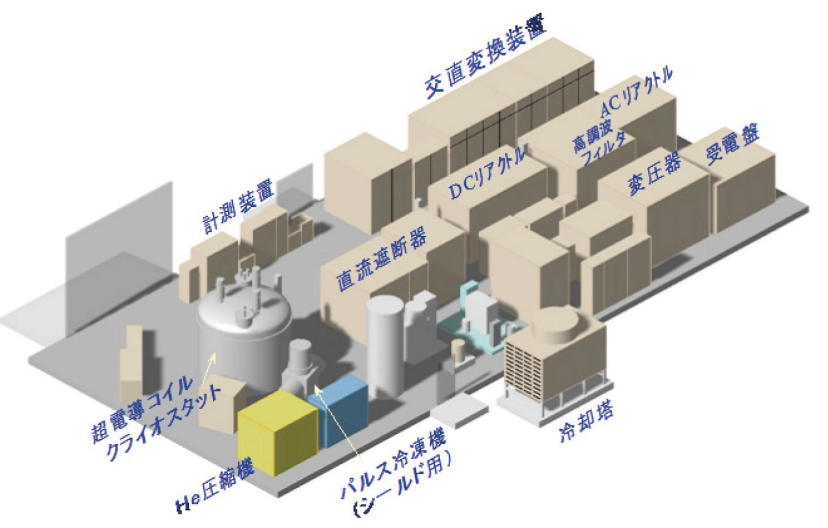

Fig. 3 Layout for components of SMES for control of power systems.

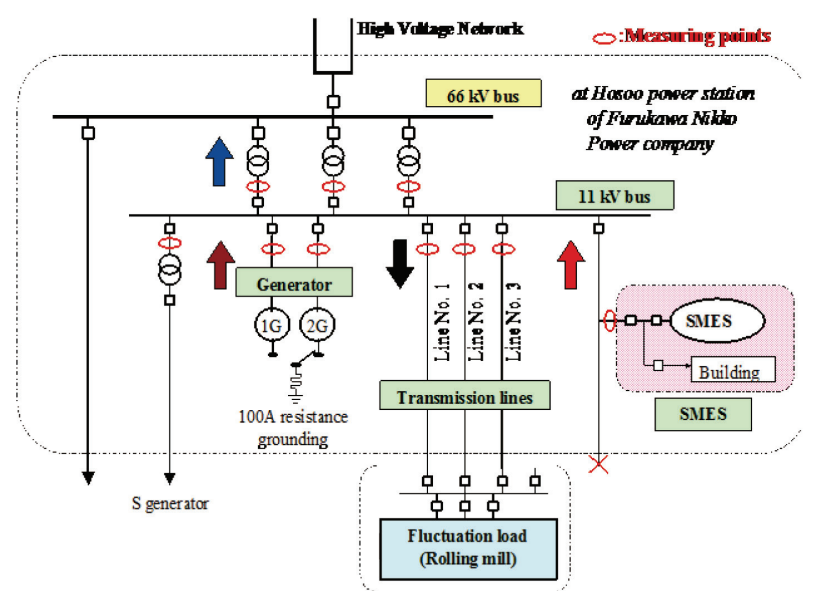

Fig. 4 Diagram of power system at field test site.

比ベエネルギー貯蔵密度が低い SMES の高磁界化は貯蔵密 度を高め、これによりコンパクト化を図ることが出来、物 量低減と冷却システムへの負荷を下げることにより、ラン ニングコストも含めた大幅なコストダウンが期待される。 2008 年から始まった第 4 期の国家プロジェクトでは、この イットリウム系超電導体の長所を生かした SMES 用超電導 コイルの構成技術の確立を図り、限界性能を把握すること を最終目的とした開発が進められた。

イットリウム系超電導体は、製造技術の開発・発展によ り長尺線材が製作されるようになってきたが、コイル化に 際しては引っ張りに強いイットリウム系線材が厚さ方向 の応力で積層構造の薄膜に剥離が生じるという問題が生 じた。そこで、Yoroi ( $\underline{Y}$-based oxide superconductor and reinforcing outer integrated）- coil と称するコイル化技術によ り、イットリウム系線材の弱点を克服して高強度コイルの 実現を図った。Yoroi-coil では、超電導線材に作用する電磁 力を超電導線材だけでなく、コイルの面方向の側板で支え ることによって、超電導線材の強度の限界を超える電磁力 に耐えることを可能にしている。東北大学金属材料研究所 強磁場センターで、Fig. 5 に示寸試作コイルを用いて電磁 力により広がろうとする力（以下、フープカと記す。）に 
対する耐力を検証した。液体へリウム中、8 $\mathrm{T}$ の外部磁場 の下、評価設備の電源の限界 1,500 A までコイル通電した 結果、コイルに作用するフープ力は最大 $1,700 \mathrm{MPa}$ で、 $\mathrm{Y}$ 系超電導線材の引張強度をはるかに超えるという結果が得 られている ${ }^{6-8)}$ 。この新構造コイルは 2,000 MPa 級の電磁力 に耐えることが可能で、これまでのコイルの機械強度によ る制限を変え、大型の強磁場コイルでも超電導線材の通電 特性を発揮できる構造である。

\section{SMES の冷却設備}

\section{1 瞬低補償用 SMES の冷却システム}

金属系超電導コイルを用いた瞬低補償用 SMES の冷却シ ステムには、コイルや電流リード等の冷却対象に合わせた 小型冷凍機を組み合わせることで、保守・メンテナンス性 に優れ、高圧ガス保安法に関わる法定管理者が不要なシス テムが実現されている。Fig. 6 に冷却設備を含む貯蔵部の 鳥瞰図を示す。超電導コイルを極低温に保持するクライオ スタットは、超電導コイルを液体へリウムに浸漬するため のヘリウム容器と外側真空容器の隙間に輻射シールド層を 配置した真空断熱構造の容器であり、輻射シールドや電流 リードを $60 \mathrm{~K}$ 前後に冷却する GM 冷凍機が配置されてい る。また、コイルへの通電や外部からの侵入熱によってガ ス化したヘリウムを GMJT 冷凍機によって再液化すること で、ヘリウム容器内の圧力を一定に保ち、一旦液体へリウ ムを注液すれば途中で補充することなく運転を継続できる 設計となっている。

\section{2 電力系統制御用 SMES の冷却システム}

電力系統制御用 SMES のフィールド試験のために製作し た設備は、SMES 充放電の連続繰り返し運転による大きな 定常発熱を除去するために、瞬低補償用フィールド試験機 では採用しなかった再凝縮機構が採用された。Fig. 7 に電 力系統制御用 SMES フィールド試験装置の泠却系を示す。 フランスエアリキッド社製大型冷凍機（helial1000，冷凍能 力 87.5 冷凍トン）から $6.2 \mathrm{~K} 、 0.6 \mathrm{MPa}$ のヘリウムガスをク ライオスタットのバルブボックスへ送り、JT 膨張させて気 液二相流を発生させる。この気液二相流を、クライオス タット上部に取り付けられたステンレス配管をパンケーキ 状に巻いた凝縮熱交換器に通し、コイル発熱で蒸発したへ リウムガスを再凝縮させる。なお、結果的には超電導コイ ルに発生する発熱が設計值を下回ったことから、大型冷凍 機による再凝縮運転を行うことなく、瞬低補償用 SMES と 同様な GMJT 冷凍機による再凝縮運転により繰返充放電試 験が実施された。

\section{3 パルス管冷凍機の開発}

第 3 期の国家プロジェクトでは冷凍機自体の信頼性を向 上させるパルス管冷凍機の開発も行われた。パルス管冷凍 機は圧力振動を利用して断熱仕事を行うことで冷熱を発生 させる冷凍機であるが、極低温部に可動部がないことから

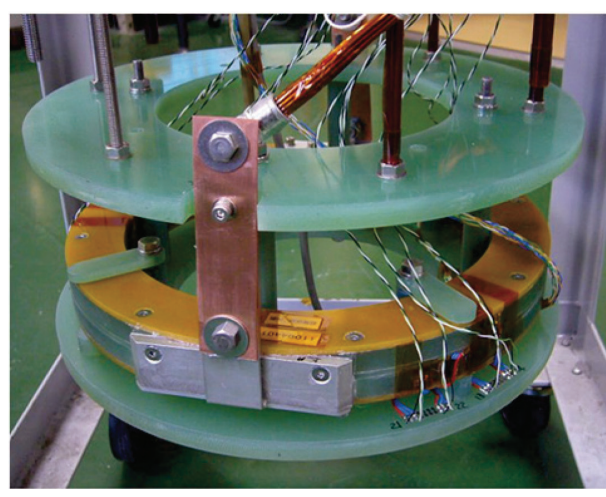

Fig. 5 Photograph of Yoroi-coil.

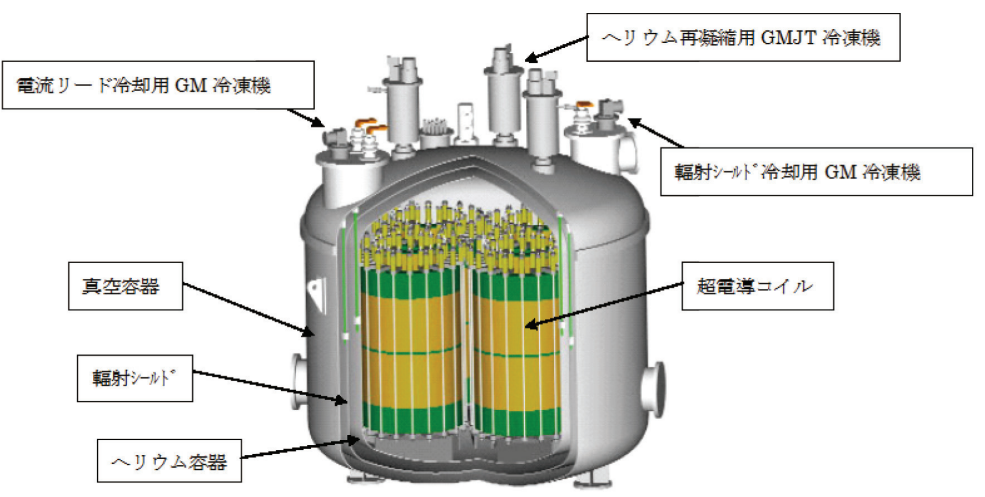

Fig. 6 Superconducting coil and cooling system image of SMES for bridging instantaneous voltage dips.

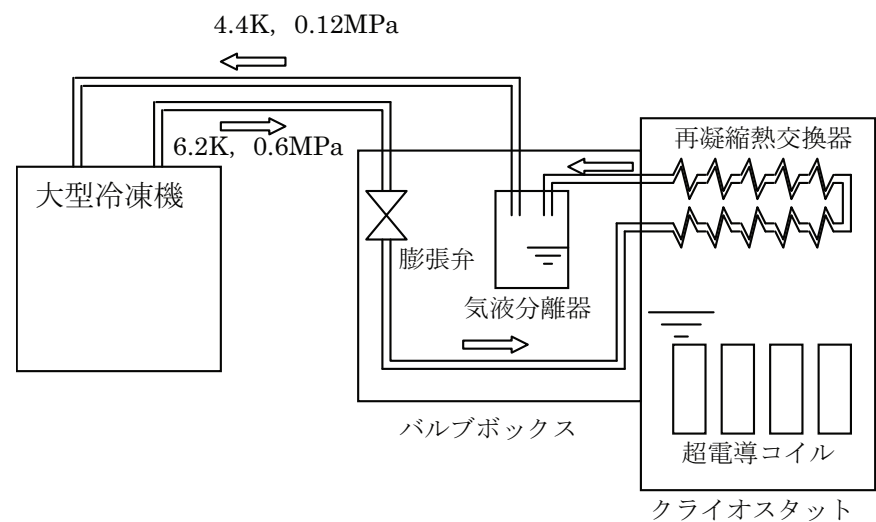

Fig. 7 Schematic diagram of the SMES cooling system for power system control.

小型化が可能で信頼性が高いという特徵を有する。開発さ れたパルス管冷凍機は従来の冷凍機と異なり、冷凍能力を 向上させるため、ヘリウムガスを膨張させる部分を 1 気筒 から世界初の 2 気筒構造とすることで出力を $300 \mathrm{~W} @ 80 \mathrm{~K}$ と高めると共に、冷凍機効率の面でも COP : 0.05 とクラス 最高を達成した。また、閉じこめたへリウムガスを圧縮・ 膨張させる部分に摩擦する部品を持たないため、摩耗によ る劣化がなく、従来機の課題であった半年毎のメンテナン 
ス間隔を 10 倍に延ばす技術的な見通しを得ている。Fig. 8 に外観、Table 2 に主な仕様を記す。

\section{4 酸化物系 SMES コイルの冷却技術}

イットリウム系超電導コイルの特性が生かされる 20〜 $40 \mathrm{~K}$ の温度領域での泠却は、従来の液体へリウムの温度 領域に比べ、超電導コイルが非常に高い熱安定性を有する ことが確認されている。この高い熱安定性を活かし、短時 間過負荷運転が SMES において可能であり、また、使用 温度の上昇により冷凍機がより高効率で運転することも可 能となる。ただし、同温度領域においては、4 K 温度領域 と異なり固体の伝熱板による熱伝導では、比熱が大きくな る分、迅速な排熱が困難となることが懸念される。このた め、Fig. 9 に示すへリウムガスを循環させることで熱の伝 達を促進させる冷却システムを開発した 9)。図中に示す圧 縮機はヘリウムガスの循環用に用いている。このシステム に SMES 評価用モデルコイルを接続し、伝導冷却による コイル特性評価を行った。モデルコイルは、Y 系線材をシ ングルパンケージ状に巻線し、絶縁処理したものを 2 層重 ね、その両表面に冷却配管を埋め込んだアルミニウム伝熱 版を取り付けた構造とした。小型冷凍機で $20 \mathrm{~K}$ 以下に冷 却したヘリウムガスを循環することで、コイル全体が 20 $\mathrm{K}$ 以下に冷却されることが確認されている。

\section{5 インバータ制御小型冷凍機の開発}

SMES では冷凍負荷が動作時と待機時では大きく異なっ ている。しかし従来の冷凍機では冷凍能力を変えることが できない。したがって最大負荷に合わせた運転をしなけれ ばならず、多くの電力を消費することとなるため、その低 減が求められる。圧縮機、冷凍機の運転周波数をインバー タ制御により可変とすることで、負荷に応じて冷凍能力を 換えられる冷凍システムとすることができる。消費電力の 低減を目的とした、 $4 \mathrm{~K} 、 20 \mathrm{~K} 、 77 \mathrm{~K}$ の能力可変高信頼性 冷凍機が開発されている。一例として $77 \mathrm{~K}$ インバータ冷 凍機について紹介すると、冷凍機駆動モータにはインバー タ用モータを使用しており、運転周波数として $80 \mathrm{~Hz}$ まで 駆動可能である。また、圧縮機はインバータ駆動用圧縮機 を使用しており、30〜 $60 \mathrm{~Hz}$ の範囲で駆動可能である。冷 凍機駆動周波数は $60 \mathrm{~Hz}$ とし、圧縮機駆動周波数を変化さ せて冷凍能力を測定した結果を Fig. 10 に示す。目標温度 に合わせた制御運転が可能となり、待機時の消費電力が従 来に比べ 4 割近く削減できることが確認されている。

\section{5. まとめ}

SMES の開発動向とその冷却設備を紹介した。SMES は、エネルギー変換効率が高く、繰返し充放電による劣化 がないことからエネルギー貯蔵部の取替えが不要となり廃 棄物の出ないシステムであるなどの特徴を有しており、瞬 低補償用途への適用・実用化も図られた技術である。今 後、既存電源や今後普及が見込まれる分散電源、風力発電

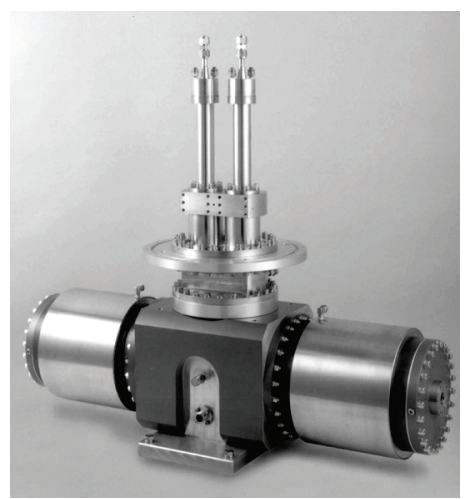

Fig. 8 Photograph of the pulse tube cryocooler.

Table 2 Specifications of the pulse tube cryocooler

\begin{tabular}{l|l}
\hline Type & Stirling pulse tube \\
\hline Cooling power & $77 \mathrm{~K} 300 \mathrm{~W}$ \\
\hline Power consumption & $7 \mathrm{~kW}$ \\
\hline Input power & $200 \mathrm{VAC} \pm 10 \%$ \\
\hline Frequency & $50 / 60 \mathrm{~Hz}$ \\
\hline Dimensions & $\mathrm{H} 800 \times \mathrm{W} 1,037 \times \mathrm{D} 700 \mathrm{~mm}$ \\
\hline Weight & $300 \mathrm{~kg}$ \\
\hline
\end{tabular}

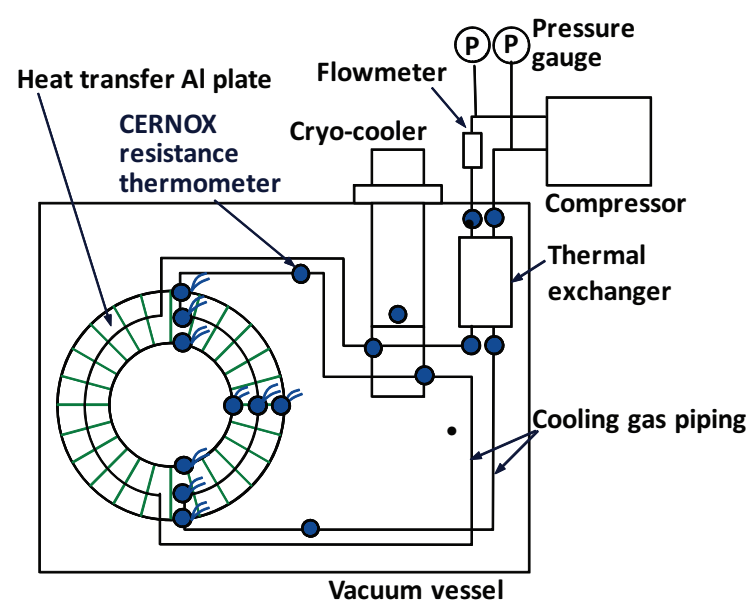

Fig. 9 Schematic diagram of the indirect cooling by circulating cryogenic He.

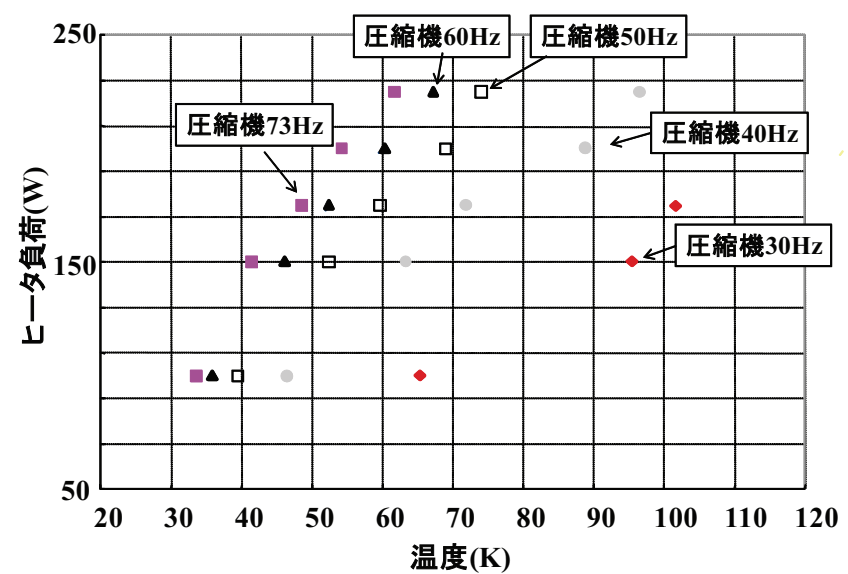

Fig. 10 Variable cooling power of a $77 \mathrm{~K}$ inverter controlled cryocooler 
等と SMES の最適な融合を図り、電力系統制御技術に寄 与する技術として一層の技術開発を展開するとともに、次 世代線材によるコイル開発など SMES の低コスト化に向 けた技術開発と、電力機器に求められる高い信頼性の検証 を推し進めていくことが重要であると考えている。特に、 超電導電力機器の信頼性を左右寸る極低温冷凍機や冷却シ ステムは極めて重要であり、開発が継続、発展することを 期待したい。

\section{参 考 文 献}

1) 例えば、SuperPower 社インターネット公開情報 http://www.superpower-inc.com/content/superconductingmagnetic-energy-storage-smes

2) A. Badel and P. Tixador: "Optimized use of superconducting magnetic energy storage for electromagnetic launcher powering", Supercond. Sci. Technol. 25 (2012) 014006 (9pp)

3) S. Nagaya, et al.: "Field test results of the 5 MVA-5 MJ SMES for bridging instantaneous voltage dips", IEEE Trans. Appl. Supercond. 16 (2006) 632

4) Y. Tatsuta, et al.: "Cost reduction measures for SMES", TEION KOGAKU 40 (2005) 141-149 (in Japanese)

辰田昌功ら：「超電導電力貯蔵システム（SMES）のコスト 低減」、低温工学 40 (2005) 141-149

5) T. Katagiri, et al.: "Field test result of 10MVA/20MJ SMES for load fluctuation compensation", IEEE Trans. Appl. Supercond. 19 (2009) 1993

6) S. Nagaya, et al.: "Development of high strength pancake coil with stress controlling structure by REBCO coated conductor", IEEE Trans. Appl. Supercond. 23 (2013) Issue:3, Part: 2, Digital Object Identifier: 10.1109/TASC.2012.2233854, Article\#: 4601204
7) T. Watanabe, et al.: "Development of high-strength pancake-coil structure: "Yoroi-coil", TEION KOGAKU 48 (2013) 213-219 (in Japanese)

渡部智則ら：「高強度パンケーキコイル構造（Yoroi-coil）の 開発」、低温工学 48 (2013) 213-219

8) Xudong Wang, et al.: "Numerical structural analysis on a new stress control structure for high-strength REBCO pancake coil", IEEE Trans. Appl. Supercond. 24 (2014) Issue: 3, Digital Object Identifier: 10.1109/TASC.2013.2288294, Article\#: 4601605

9) S. Nagaya, et al.: "Development of a high-efficiency conduction cooling technology for SMES coils", IEEE Trans. Appl. Supercond. 23 (2013) Issue: 3, Part: 2 Digital Object Identifier: 10.1109/TASC.2012.2235751, Article\#: 5602804

平 野 直 樹 1963 年生。1988 年 3 月大阪大学大学院基 礎工学研究科卒業。1998 年 3 月総合研究大学院大学博士課程修 了。現在、中部電力 (株) 電力技術研究所 超電導チーム チーム リーダ。超電導の電力応用や冷凍機開発に従事。低温工学・超電 導学会、電気学会会員、博士 (工学)。

渡 部 智 則 1964 年生。1990 年 3 月東京工業大学大学 院理工学研究科金属工学専攻修了。現在、中部電力 (株) 電力技術 研究所超電導チーム 研究主查。主として高温超電導線材に関 する研究に従事。低温工学・超電導学会会員。

長 屋 重 夫 1957 年生。1981 年 3 月名古屋大学工学部 応用化学科卒業。現在、中部電力 (株) 電力技術研究所 超電導 チーム 研究主查。主として超電導の電力応用に関する研究に従 事。低温工学・超電導学会、電気学会会員。 